\title{
Petrography, geochemistry and regional significance of crystalline klippen in the Garhwal Lesser Himalaya, India
}

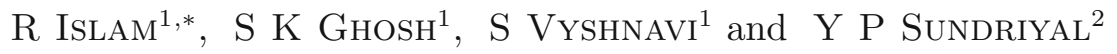 \\ ${ }^{1}$ Wadia Institute of Himalayan Geology, Dehradun 248 001, India. \\ ${ }^{2}$ Department of Geology, H.N.B. Garhwal University, Srinagar 246 174, India. \\ *e-mail: rislam@wihg.res.in
}

Uphalda gneisses (UG) is a crystalline klippe located near Srinagar in Garhwal Himalaya. These gneisses are compared with Debguru porphyroids (DP) ( $\approx$ Ramgarh group) of Garhwal-Kumaun Himalaya and Baragaon mylonitic gneisses (BMG) of Himachal Himalaya. Petrographic study reveals that the deformation of UG was initiated at higher temperature (above $350^{\circ} \mathrm{C}$ ) and continued till lowering of temperature and deformation led to the mylonitization.

Geochemically, these granitic gneisses (UG, DP and BMG) exhibit similar composition. Features such as high molecular $\mathrm{A} / \mathrm{CNK}$ value $(>1)$, presence of normative corundum and absence of normative diopside, enhanced $\mathrm{Rb} / \mathrm{Sr}, \mathrm{Rb} / \mathrm{Zr}$ ratios, enrichment of $\mathrm{Th}$ and containing rounded zircons support their crustally-derived S-type granitic nature. The linear plot in major oxides is interpreted in terms of fractional crystallization processes. Mantle normalized multi-element spider diagram of UG illustrates depletion of $\mathrm{Ba}, \mathrm{Nb}, \mathrm{Sr}, \mathrm{P}$ and $\mathrm{Ti}$ and enrichment of Th and show similarities with DP and BMG.

Similarities were observed in lithology, petrographic characters and chemical composition of UG, DP, BMG and Ulleri augen gneisses (Nepal). Comparison with the rocks of Higher Himalayan crystallines $(\approx$ Vaikrita), suggests that these rocks $(\mathrm{UG})$ are not transported from Higher Himalaya as understood earlier. This study however proposes that, these gneissic bodies represent an older basement occurring as a tectonic sliver which emplaced within the cover sequence as wedges at different structural levels. This is a regional phenomena observed throughout the Lesser Himalayan region.

\section{Introduction}

The Garhwal-Kumaun Himalaya stretches from the Kali river in the east to Tons-Pabbar valleys in the west. The region is approximately $300 \mathrm{~km}$ long and $125 \mathrm{~km}$ wide. Pioneering studies have been carried out on Garhwal-Kumaun Himalaya by Medlicott (1864), Oldham $(1883,1885)$ and Middlemiss $(1885,1887,1890)$. In the 20th century, significant studies were carried out by Auden (1934, 1937) and Heim and Gansser (1939). Valdiya
(1980) gave a comprehensive picture on the structure and stratigraphic details of the region.

In recent years, considerable number of studies have been carried out on the Main Central Thrust (MCT) after its early discovery by Heim and Gansser (1939). This structure is widely responsible for the development of the Himalaya; however its location is highly debated (Kohn et al 2002; Searle et al 2002). The lower and upper bounding faults of MCT zones have been termed as MCTI and MCT-II in Nepal (Hashimoto et al 1973;

Keywords. Lesser Himalaya; geochemistry; crystalline klippen; Uphalda gneisses; tectonic sliver. 
Arita 1983), Munsiari and Vaikrita thrust in the Garhwal-Kumaun region (Valdiya 1980).

The Lesser Himalayan sequence is restricted to a zone between Main Boundary Thrust (MBT) in the south and Vaikrita thrust $(\approx \mathrm{MCT})$ in the north. Ahmad et al (2000) studied the combined isotope and trace elements of major lithologies of the Garhwal-Kumaun sector in order to identify the location of the MCT and traced the entire length of the Himalayan orogen. Many workers have divided Lesser Himalaya into older and younger regions (Valdiya 1980; Srivastava and Gairola 1990; Srivastava and Mitra 1994; Ahmad et al 2000; DeCelles et al 2001; Richards et al 2005; Célérier et al 2009).

In between MBT and Vaikrita thrust $(\approx \mathrm{MCT})$, there lie a number of thrusts such as Ramgarh thrust, North Almora thrust, Tons thrust and Munsiari thrust; often some of these are folded. Structurally, there lie two major thrust sheets in Lesser Himalaya, viz., Ramgarh thrust sheet and Munsiari thrust sheet. In addition, there are several klippen (e.g., Almora, Satengal, Banali, Amri, Bijni, etc.) located in the parautochthonous zone of Lesser Himalaya with their root zone lying in the Higher Himalaya. A few of these klippen have been re-examined in terms of modern concepts of thrust tectonics and the earlier models revised (Bali and Bhattacharya 1988; Dubey and Bhat 1991; Srivastava and Mitra 1994; Jayangondaperumal and Dubey 2001; Devrani and Dubey 2008). Consequently, their origins are still enigmatic and are yet to be deciphered in terms of their source region. In Garhwal-Kumaun Himalaya at Srinagar, a small klippe named as Uphalda gneisses (UG) (Doval and Saklani 1980) is present and correlated to Muliagaon gneisses of Pratapnagar (Saklani 1972). A suite of granitic porphyry termed as Debguru porphyroids (DP) (Heim and Gansser 1939; Valdiya 1980) is located at the base of the Ramgarh thrust sheet; their stratigraphic position and origin is a matter of disagreement which is yet to be resolved. Compositionally and texturally, DP ( $\approx$ Ramgarh $)$ are different from Augen gneisses of the Almora klippe (Valdiya 1980). Similarly, a sheet-like body occurs at the basal part of the Chail thrust sheet with a maximum thickness of $800 \mathrm{~m}$ known as Baragaon mynonitic gneisses (BMG) in Himachal Himalaya (Gururajan 1990). Compositionally, DP and BMG are similar to UG.

The main purpose of this study is to comprehend the origin and source of the UG based on field and laboratory data and its comparison with DP of Garhwal-Kumaun and BMG of Himachal Himalaya; and to unravel the occurrence of these gneisses as tectonic slivers within the metasedimentary piles of the Lesser Himalaya. This may lead to an understanding of the status of various klippen existing in various sectors of the Lesser Himalaya.

\section{Geological setup}

The Lesser Himalayan region (figure 1a) is divided into Inner and Outer Lesser Himalayan sequences, separated by North Almora thrust (NAT)/Tons thrust (TT) (Ahmad et al 2000). The investigated area is located in the Outer Lesser Himalayan zone of Garhwal Kumaun Himalaya around Srinagar. The Inner Lesser Himalaya is more proximal to the south of the Indian shield than the Outer Lesser Himalaya (Ahmad et al 2000). The authochthonous unit of the Proterozoic sediments of Damtha and Tejam groups is exposed at the vast window in the inner (northern) belt of the Lesser Himalaya. The Outer Lesser Himalaya mostly consists of the Jaunsar and Mussoorie group (Valdiya 1980). Lithostratigraphically, it comprises Mandhali at the base, succeeded by the Chandpur and Nagthat formations of the Jaunsar group, forming the bulk of the tectonic unit and are capped by the Late Neoproterozoic Krol (mostly limestones) and Tal (mostly siliciclastics) formations. The trilobite fossils from the Tal formation belong to the Early Cambrian (Hughes et al 2005). Cretaceous to Paleocene shelly limestone and sandstone of Bansi and Subathu formations have limited exposure to the south of the TT in the Garhwal Lesser Himalayan sequence.

The northern boundary of Almora klippe marked by the NAT acts as a barrier between Outer and Inner Lesser Himalaya and separates Chandpur phyllites from Khirsu quartzite (Rautgara of Valdiya 1980) of Kumar and Agarwal (1975). Below the NAT, a thick succession of phyllites of Chandpur Formation is exposed and severed by small basic dykes at Kilkilleshwar $(3 \mathrm{~km}$ south of Srinagar). Lens-shaped mylonitized granitic gneiss bodies which are exposed at Uphalda are named as UG (figure 1b) by Doval and Saklani (1980). The contact between UG and Chandpur formation is thrusted. These UG are broadly similar to the suite of quartz porphyry of Valdiya's DP.

Chandpur formation consists of phyllite, slate, shale and quartzite. The Chandpur phyllite of Srinagar area is also referred to as Pauri phyllite. These rocks are greyish green to dark green in colour and are folded and schistose in nature at Uphalda. The crenulation cleavage is quite prominent. A patchy outcrop of ferruginous quartzite appears in the form of a tectonic window, $4.5 \mathrm{~km}$ SE of Srinagar (Doval and Saklani 1980). The basic dykes are hard and compact and cut across the phyllites of Chandpur formation. Dykes are foliated at the margin and the core portion is fresh and compact.

The UG are biotite-rich mylonitic augen gneisses and are characterized by alternate bands of quartz, feldspar and micas. These rocks are intensely and 


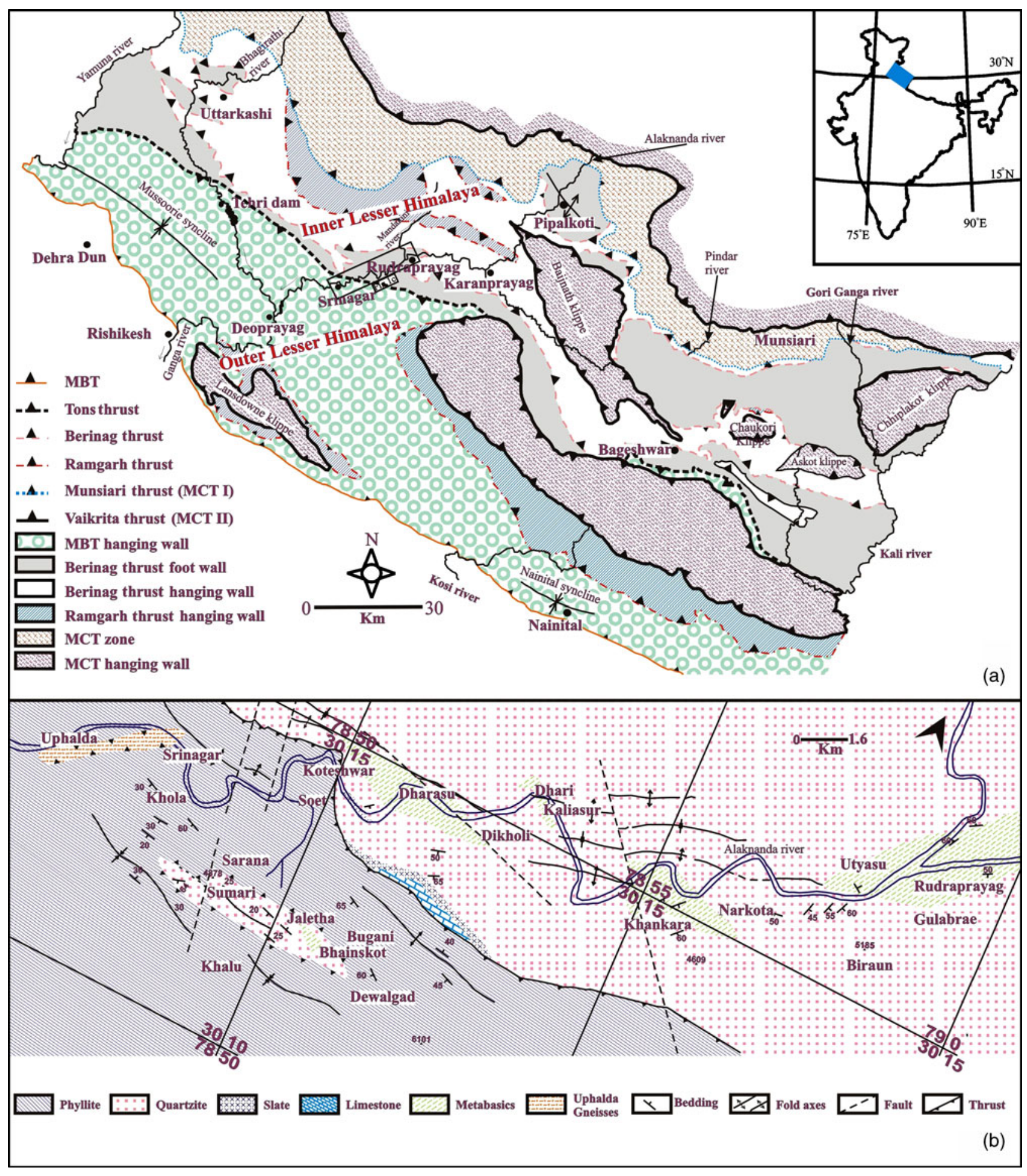

Figure 1. (a) Geological and structural map of the Garhwal-Kumaun Lesser Himalaya. It represents the major structure of the region, various klippen, a series of stacked thrust sheets, major drainages and township of the region. Abbreviations MBT: Main Boundary Thrust; MCT: Main Central Thrust (modified after Valdiya 1980; Célérier et al 2009). (b) Geological map of the study area, shows the various locations, structural details such as Uphalda klippe, etc. (modified after Doval and Saklani 1980). Rectangle in the map (a) shows the location of (b).

pervasively mylonitised, sheared, foliated and strongly recrystallized to blastomylonites. The UG is in direct contact with Chandpur phyllite and the contact is sharp.

\section{Petrography}

The UG show characteristics of mylonite that is defined by grain-size reduction of quartz and 
feldspars with a well-developed foliation plane. The rock has a mineral assemblage of quartz, alkali feldspar, plagioclase, biotite and muscovite with minor amount of apatite, zircon, calcite, epidote and Fe-oxide. The preferred orientation of mica defines the foliation plane.

Quartz commonly occurs as coarse porphyroclast with small recrystallized grains at the
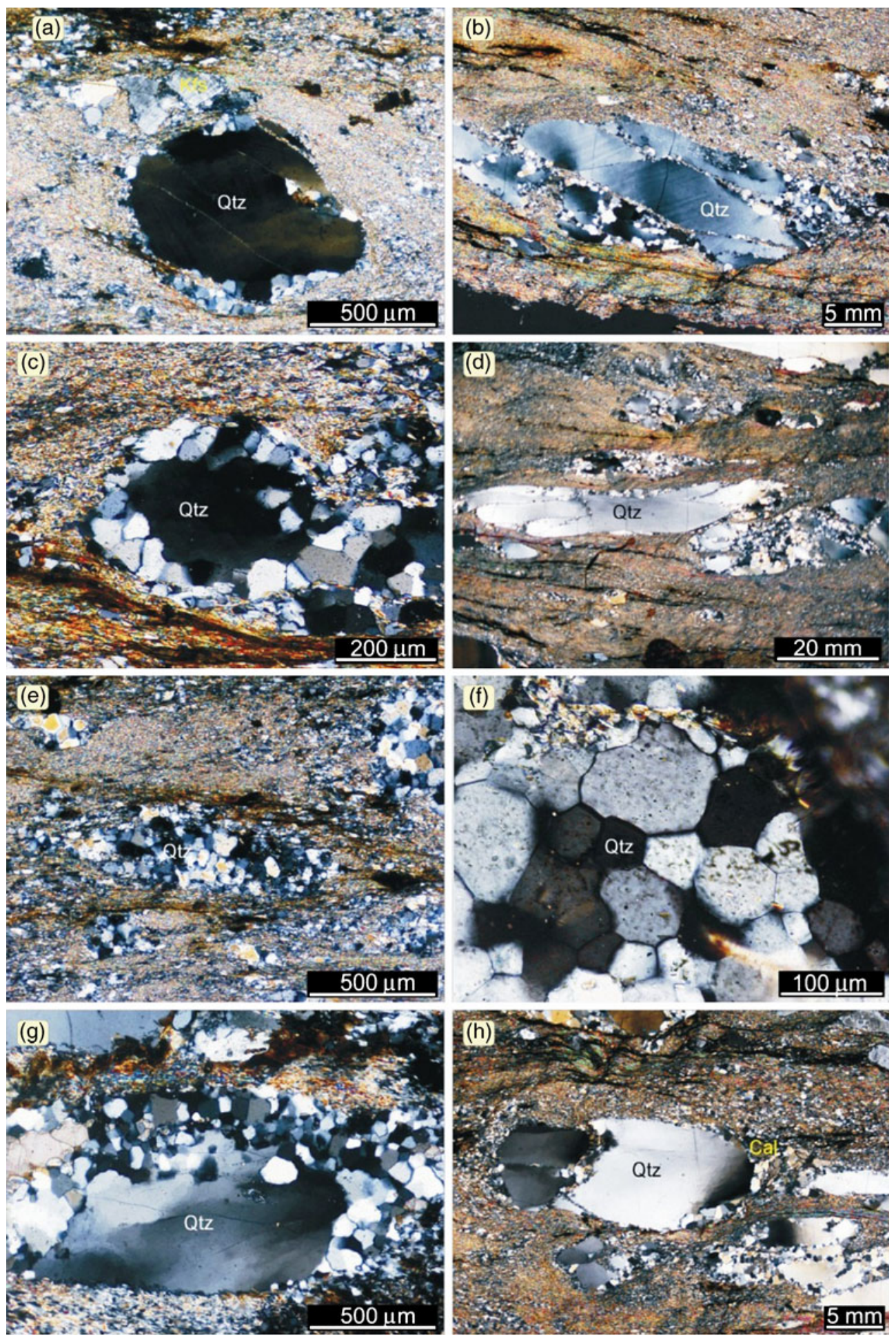

Figure 2. Representative photomicrograph of UG of Garhwal Lesser Himalaya showing various mylonitic characters of the rock. (a) Quartz porphyroclast with small recrystallized grains at the margin, (b) undulose extinction and deformation lamellae in UG, (c) quartz (at the centre) showing core-mantle structure, (d) ribbon structure observed in UG, (e) completely recrystallized quartz ribbon, (f) recrystallized grains having straight boundaries meet at triple-point junction, (g) polycrystalline quartz with irregular grain boundaries, and (h) recrystallized quartz grains and calcite are in the pressure shadow region. (All photographs are taken under XPL.) 
margin with fine grained groundmass (figure 2a). The porphyroclast is wrapped by foliation and shows ductile deformation features such as undulose extinction, deformation lamellae and development of sub-grains (figure 2b). It exhibits core-mantle structure as well as ribbon structure that is elongated and stretched along the foliation (figure 2c, d). At a few places, totally recrystallized quartz ribbons are also observed (figure $2 \mathrm{e}$ ). The recrystallized grains form small equate patches of polygonal grains having straight or sutured grain boundaries (figure 2f) and meet at triple-point junctions. Irregular grain boundaries in quartz suggest grain boundary migration phenomena (figure $2 \mathrm{~g})$. At places, recrystallized quartz grains and calcite are concentrated in the pressure shadow regions of the quartz porphyroclast (figure $2 \mathrm{~h}$ ). Fractures filled with mica and fine-grained quartz in porphyroclast are also present. Microstructural features suggest that the quartz have undergone both ductile and brittle deformations.

Alkali feldspar occurs as coarse porphyroclast in the form of augen and small grains associated with quartz and micas as groundmass. The porphyroclast is wrapped up by the foliation defined by the alignment of fine-grained mica and exhibits crosshatched twinning and perthitic texture (figure 3a). It also shows undulose extinction and at places, the foliation passes through the porphyroclast (figure $3 \mathrm{~b}$ ). Along the fracture(s) the K-feldspar is broken into
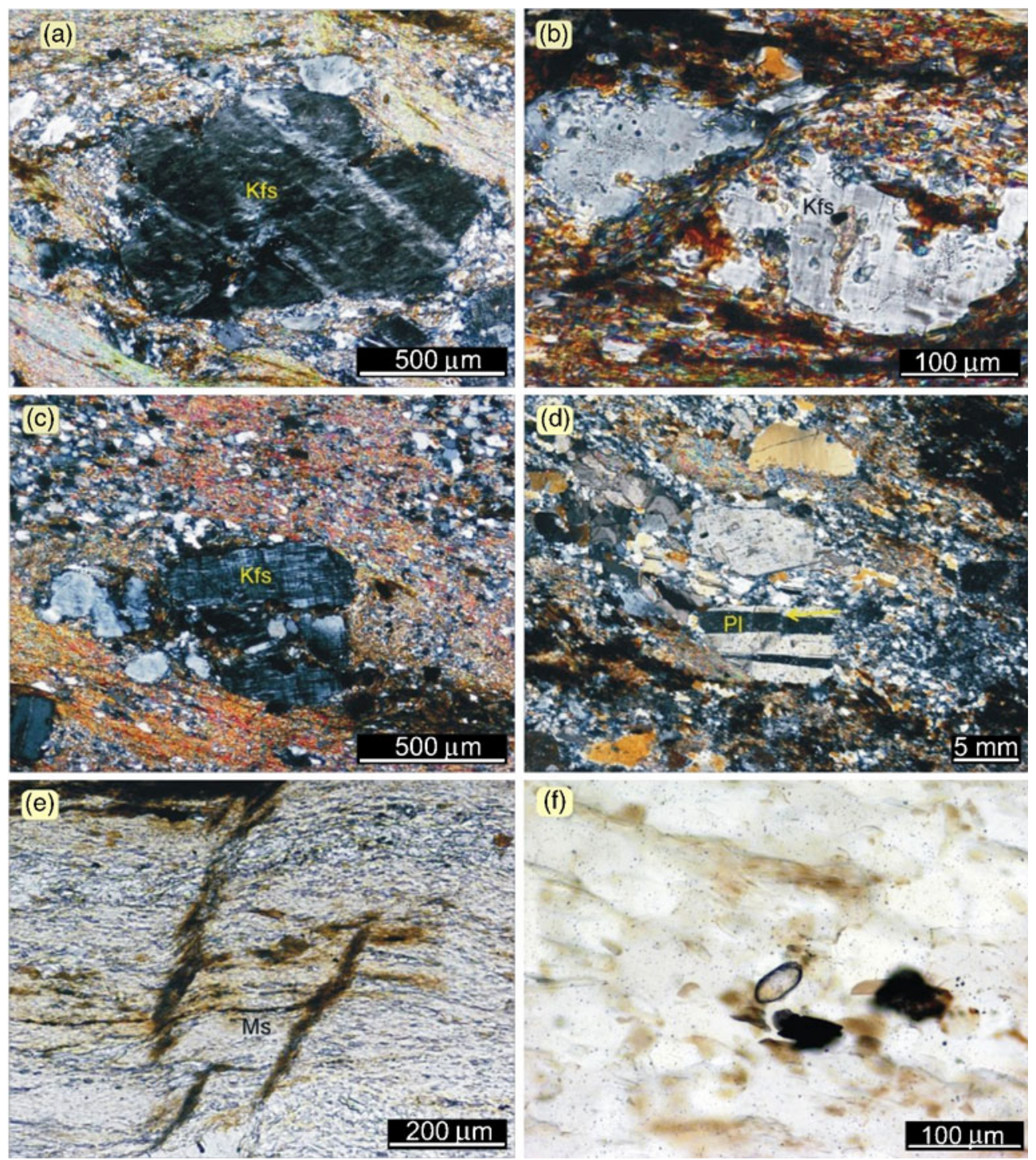

Figure 3. Representative photomicrograph showing (a) K-feldspar porphyroclast wrapped by foliation, (b) foliation passing through the K-feldspar porphyroclast, (c) microcline twinning and the porphyroclast is broken into small grains and distributed in the groundmass, (d) displaced twin lamellae along the fracture (arrow) of plagioclase porphyroclast and broken into small grains, (e) folded foliation and development of crenulation cleavage, and (f) rounded grains of zircon support their sedimentary parentages. (All photographs are taken under XPL except (e), (f) taken under PPL). Mineral abbreviations are after Kretz (1983): quartz (Qtz), K-feldspar (Kfs), plagioclase (Pl), muscovite (Ms), biotite (Bt), calcite (Cal). 
small grains and disseminated in the groundmass, suggesting that fracturing occurs later than the early crystal ductile deformation (figure $3 \mathrm{c}$ ). The $\mathrm{K}$-feldspars are less altered than the plagioclase.

Plagioclase occurs both as porphyroclast and fine-grained groundmass. In most of the samples, the plagioclase is completely altered. Plagioclase porphyroclasts are subhedral to anhedral with sutured boundaries and highly altered at the rim. They show undulose extinction and tapering deformation twins. In some cases, the fractures in the porphyroclast of plagioclase are developed by cutting across the twin lamellae and displacing the twin lamellae along the fracture and breaking the porphyroclast into small grains (figure 3d). Patches of plagioclase occur as islands in K-feldspar. The alteration product calcite shows twinning. Both plagioclase and $\mathrm{K}$-feldspar are plastically deformed, however fracturing mechanism is more dominant in these minerals. Dynamic recrystallization of feldspars is not observed because the dissolution processes were dominant or the recrystallized domains around the feldspars have been dissolved or replaced by micas under low temperature conditions aided by flow of fluids.

Muscovite shows a strong preferred orientation and defined main foliation. It is very fine grained. At places, the main foliation is folded with development of crenulation cleavage (figure 3e). Sericite, which is the alteration product of feldspar, is also present. Biotite occurs as fine flakes lying along the foliation. The modal content of biotite is less than muscovite. More likely, the biotite has been destabilized and converted into secondary minerals. Similar types of petrographic characters are observed for DP and BMG.

The mineral assemblages in the UG exhibit greenschist facies condition. The mineral assemblages in the surrounding Chandpur formation are also metamorphosed to greenschist facies condition. The micas, especially recrystallized biotite are affected by chloritization. Albite, microcline and quartz also exhibit recrystallization phenomena. Crystallized plagioclase is of albitic composition indicating that recrystallization has occurred at lower temperatures. Recrystallization of muscovite, epidote, quartz and albite from the deformationinduced retrogression of plagioclase reveals that the deformation has taken place at greenschist facies conditions.

\section{Analytical techniques}

Sixteen samples representing UG (11) of Srinagar area, DP (2) and BMG (3) were collected. These samples were analysed for major, trace and rare earth elements (REE) at Wadia Institute of Himalayan Geology, Dehradun. Geochemical analyses were performed using standard X-RF techniques, analysed by wavelength dispersive $\mathrm{X}-\mathrm{RF}$ system (Siemens SRS 3000) and inductively coupled plasma-mass spectrometry (ICP-MS). The calibration of $\mathrm{X}-\mathrm{RF}$ system was done by matrix correction based on intensities (Lucas-Tooth and Pyne 1964). Using a number of international standards (such as G2, GSP-1, JG-1, JG-2, DG-H) along with the samples, we monitored the quality of the analysis. Trace and REE analyses were carried out on ICP-MS (Perkin Elmer), with $0.4 \mathrm{~g}$ of the sample, following a long process of acid digestion that involved repeated treatment with $\mathrm{HF}-\mathrm{HClO}_{4}$ in the ratio of $2: 1$. The samples were dissolved in the acid mixture for two to three treatments until a clear solution was obtained. The residue was dissolved in $1 \mathrm{~N} \mathrm{HNO}_{3}$ and $100 \mathrm{ml}$ solution was then ready for analysis. Precision for the major oxides was always better than $1.5 \%$, for $\mathrm{P}_{2} \mathrm{O}_{5}, \mathrm{MnO}$ and trace elements it was better than $5 \%$, and for REE better than 10\% (Ahmad et al 1996).

\section{Geochemical characteristics}

The geochemical analysis of UG, DP and BMG are presented in table 1 . The overall major oxide behaviour of UG, DP and BMG are identical. These rocks are rich in $\mathrm{SiO}_{2}$ content, ranging between 65 and $70 \mathrm{wt} \% ; \mathrm{Al}_{2} \mathrm{O}_{3}$ exhibits a narrow range (15-18 wt\%). UG are also rich in $\mathrm{Fe}_{2} \mathrm{O}_{3}$ and $\mathrm{K}_{2} \mathrm{O}$ content. To demonstrate the nature of these rocks, $\mathrm{A} / \mathrm{CNK}$ ratios were derived (where molecular $\mathrm{A} / \mathrm{CNK}=\left\{\right.$ mol. $\left[\mathrm{Al}_{2} \mathrm{O}_{3} /\left(\mathrm{CaO}+\mathrm{Na}_{2} \mathrm{O}+\right.\right.$ $\left.\left.\left.\mathrm{K}_{2} \mathrm{O}\right)\right]\right\}$, which range between 1.24 and 2.37 (UG: 1.39-0.37, DP: 1.28-1.45, BMG: 1.24-1.46), suggesting their peraluminous nature. The more leucocratic samples are very peraluminous. All the samples show the presence of normative corundum and absence of normative diopside; presence of round zircon grains support their sedimentary parentages (figure 3f). Alkali content $\left(\mathrm{Na}_{2} \mathrm{O}+\right.$ $\left.\mathrm{K}_{2} \mathrm{O}\right)$ of $\mathrm{UG}$ is high $(>6$ wt $\%) . \mathrm{K}_{2} \mathrm{O}$ content is always greater than $\mathrm{Na}_{2} \mathrm{O}$. High $\mathrm{K}_{2} \mathrm{O}$ content suggests preponderance of microcline in these rocks. DP and BMG also exhibit similar characteristics. The major oxide composition of UG along with DP and BMG are plotted in Harker's variation diagram. $\mathrm{TiO}_{2}, \mathrm{Al}_{2} \mathrm{O}_{3}, \mathrm{Fe}_{2} \mathrm{O}_{3}, \mathrm{MgO}$ and $\mathrm{Na}_{2} \mathrm{O}$ exhibit negative trend with $\mathrm{SiO}_{2}$, whereas $\mathrm{CaO}$ and $\mathrm{K}_{2} \mathrm{O}$ do not show linear trend (figure 4). Owing to similar composition, the characteristics of these rocks are similar. The $\mathrm{Fe}_{2} \mathrm{O}_{3}$ vs. $\mathrm{MgO}$ plot (figure not shown) exhibit a positive trend indicating that they are constantly controlled by biotite crystallization. Relatively high Ti concentration, but lack 


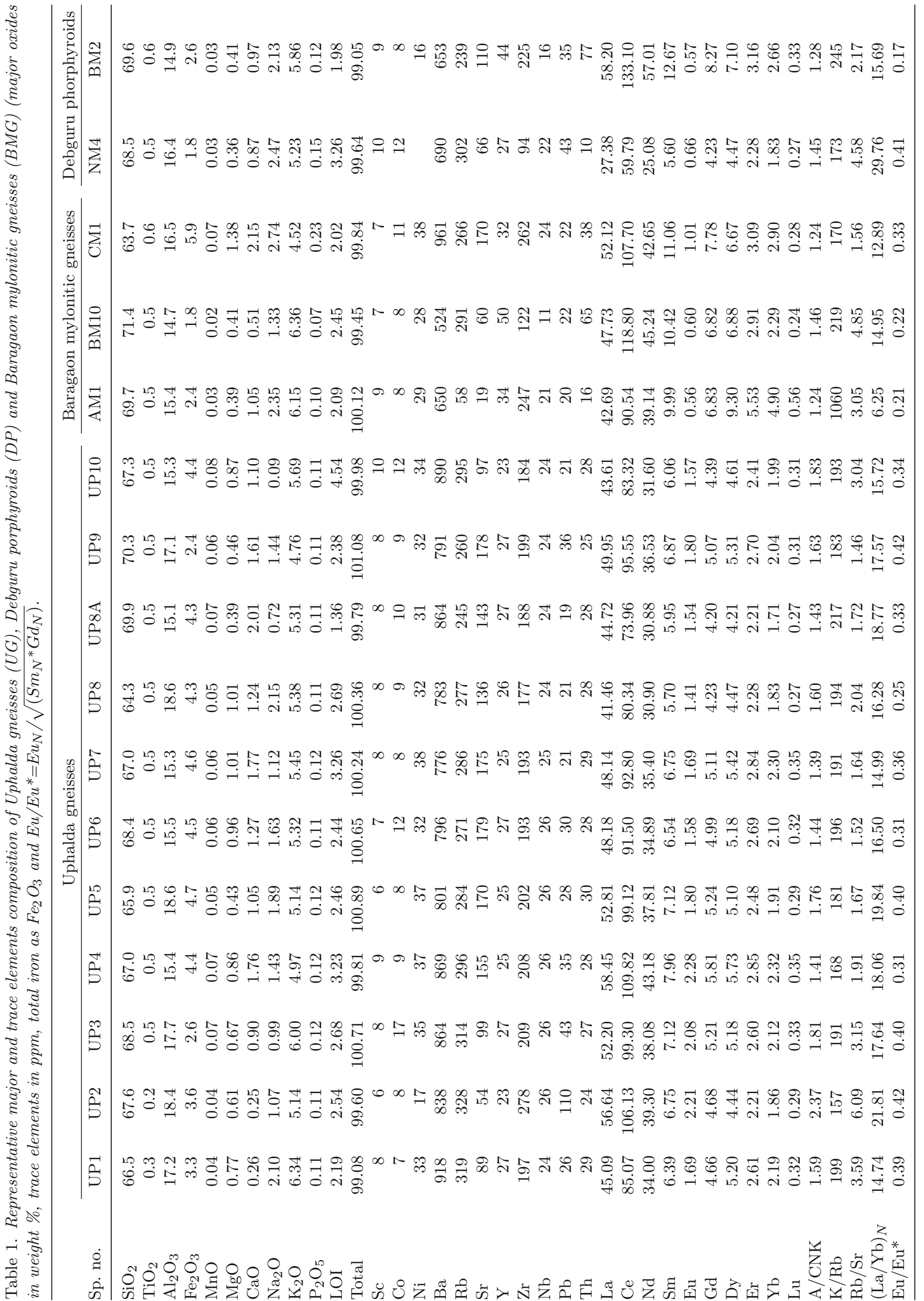




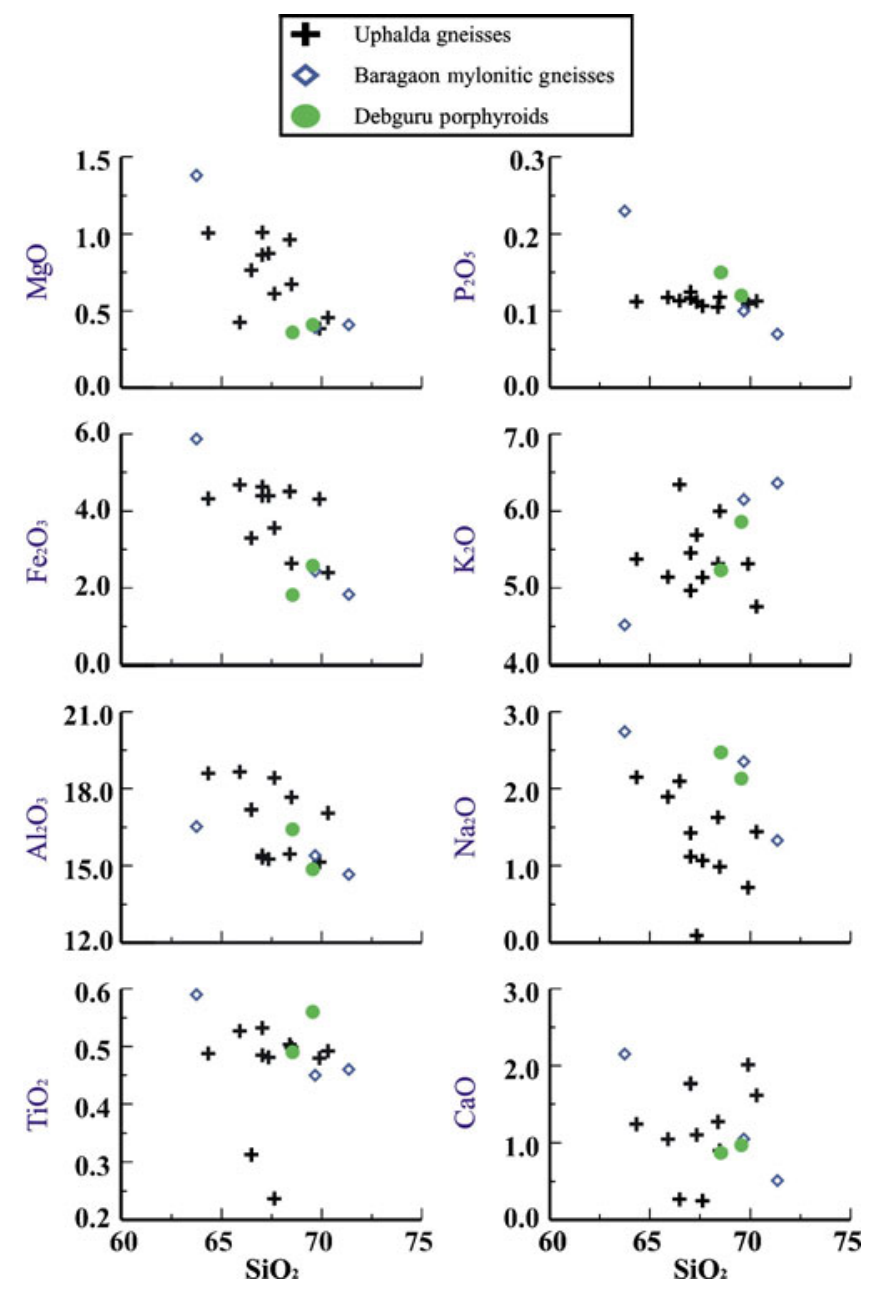

Figure 4. Harker's variation diagram of UG (black plus), BMG (empty rhomb) of Himachal Himalaya and DP (filled dots) of Garhwal Lesser Himalaya, showing binary relationship with $\mathrm{SiO}_{2}$ vs. all major oxides.

of titanium phase, suggests the involvement of biotite during melting. Among the trace elements, $\mathrm{Ba}, \mathrm{Sr}, \mathrm{Zr}$, Th and $\mathrm{Nb}$ show a negative trend with $\mathrm{SiO}_{2}$ and $\mathrm{Rb}$ does not show any trend but cluster at one place in Harker's variation diagram (figure 5), however these elements show a comparatively better trend with $\mathrm{Zr}$. In general, the $\mathrm{UG}$ are rich in $\mathrm{Rb}, \mathrm{Ba}, \mathrm{Zr}$, depleted in $\mathrm{Sr}$ and transition elements (Co, Ni, etc.). Similar characteristics are also exhibited by BMG and DP ( $\approx$ Ramgarh group of rocks). The general enrichment of LILE (K, Rb, etc.) and depletion of HFSE (Zr, Y, Nb) support their crustal source. To demonstrate crystal fractionation of feldspar and biotite, $\mathrm{Sr}$ and $\mathrm{Ba}$ are plotted against $\mathrm{Rb} / \mathrm{Sr}$ ratio (figure 6) and $\mathrm{Ba}$ vs. Rb plots (figure 7a). A very good negative trend is observed particularly in the $\mathrm{Sr} v s$. Rb/Sr diagram. The bulk distribution coefficient $(\mathrm{Kd})$ for $\mathrm{Ba}$ and $\mathrm{Sr}$ will be $>1$ and for $\mathrm{Rb}<1$, hence the fractional crystallization will result in decreasing $\mathrm{Sr}$ and $\mathrm{Ba}$ and enhancement
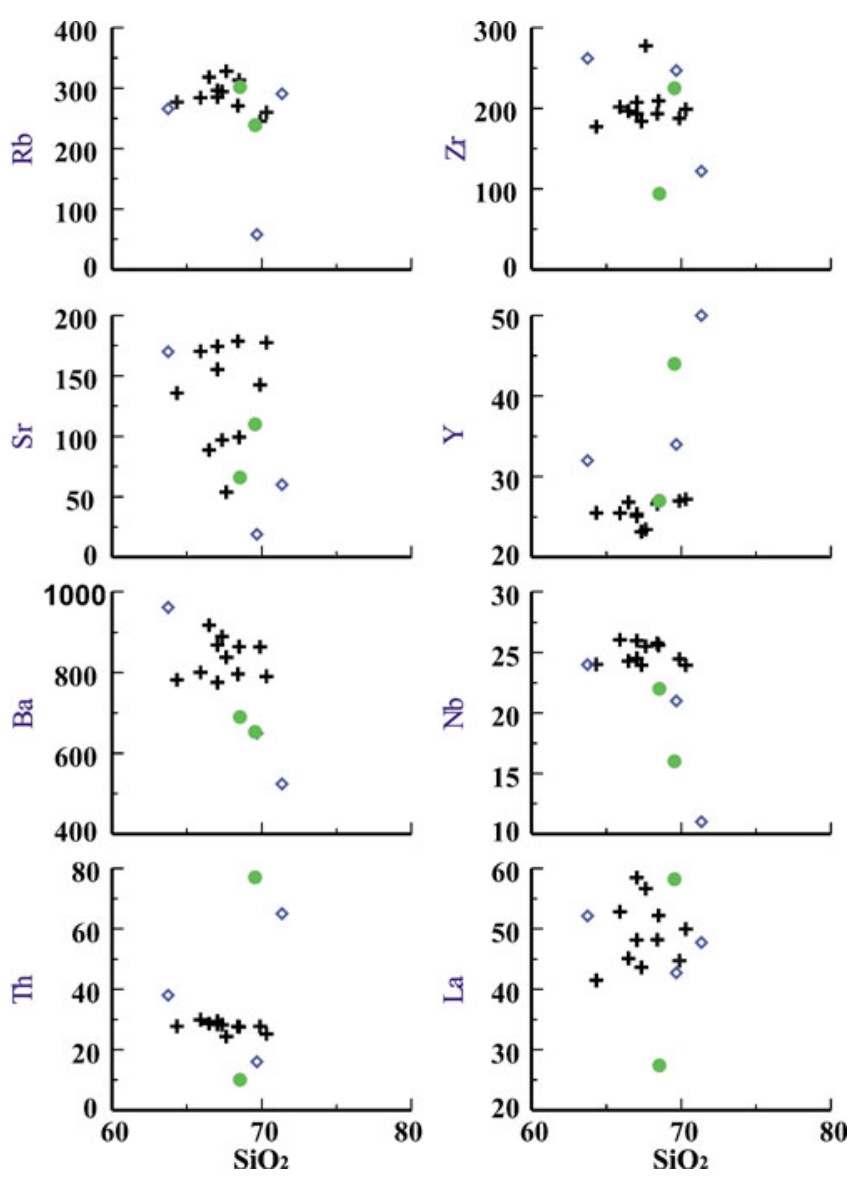

Figure 5. Harker's plots of $\mathrm{SiO}_{2}$ vs. trace elements of UG (black plus), BMG (empty rhomb) of Himachal Himalaya and DP (filled dots) of Garhwal Lesser Himalaya.

of $\mathrm{Rb}$. The depletion of $\mathrm{Sr}$ is in accordance with plagioclase fractionation. The above cited trends suggest that fractionation was dominated by Kfeldspar and biotite and are increasingly important in more evolved stages. Further, positive correlation between $\mathrm{Zr}$ and $\mathrm{TiO}_{2}$ is best explained by fractional crystallization processes (figure $7 \mathrm{~b}$ ).

REE of UG, BMG and DP are analysed and their values are normalized after Sun and McDonough (1989) and are presented in table 1. UP are characterized by high LREE abundances (chondrite normalized La 100-290X) and the HREE abundances vary between $10 \times$ and $20 \times \mathrm{Lu}$ (figure $8 \mathrm{a}$ ). The ratios of $(\mathrm{La} / \mathrm{Yb})_{N},(\mathrm{La} / \mathrm{Sm})_{N},(\mathrm{Gd} / \mathrm{Yb})_{N}$ and $\mathrm{Eu}_{N} / \mathrm{Eu}^{*}$ (where $\mathrm{Eu}^{*}$ is the square root of the products $\mathrm{Sm}_{N}$ and $\mathrm{Gd}_{N}$ ) are calculated and suggest moderately fractionated nature of UG. Similar characteristics are also exhibited by BMG and DP. The concentration of total REE and degree of fractionation increases from leucocratic to melanocratic variety of rocks. Involvement of REE-rich accessory minerals such as monazite and zircon are abundant in UG, DP and BMG. Variations in REE patterns can also be explained in terms of simple crystal fractionation. Positive correlations between 

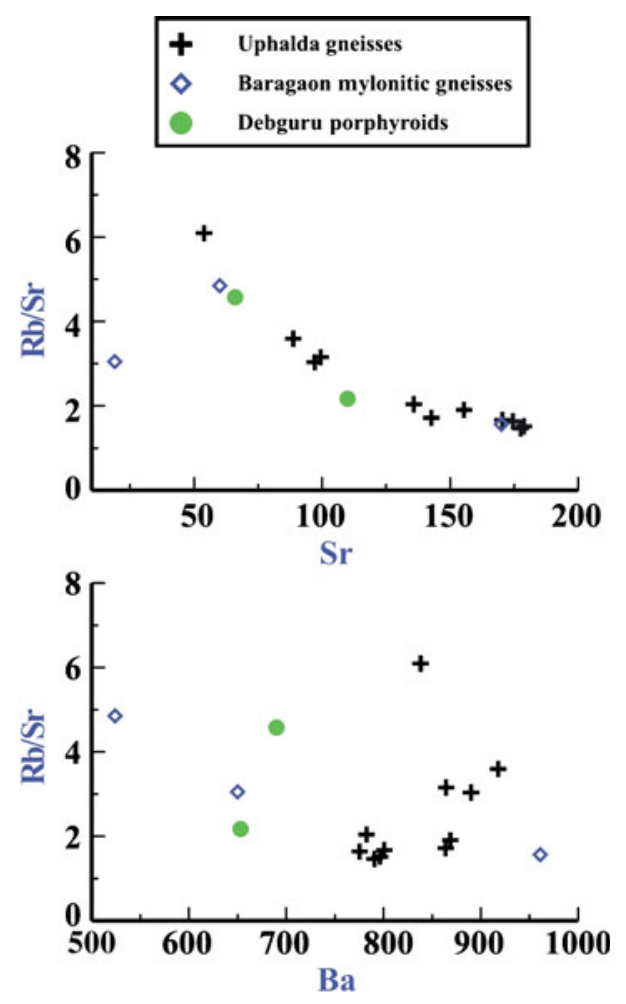

Figure 6. LILE covariation plots of UG, DP and BMG. Symbols are as in figure 4.
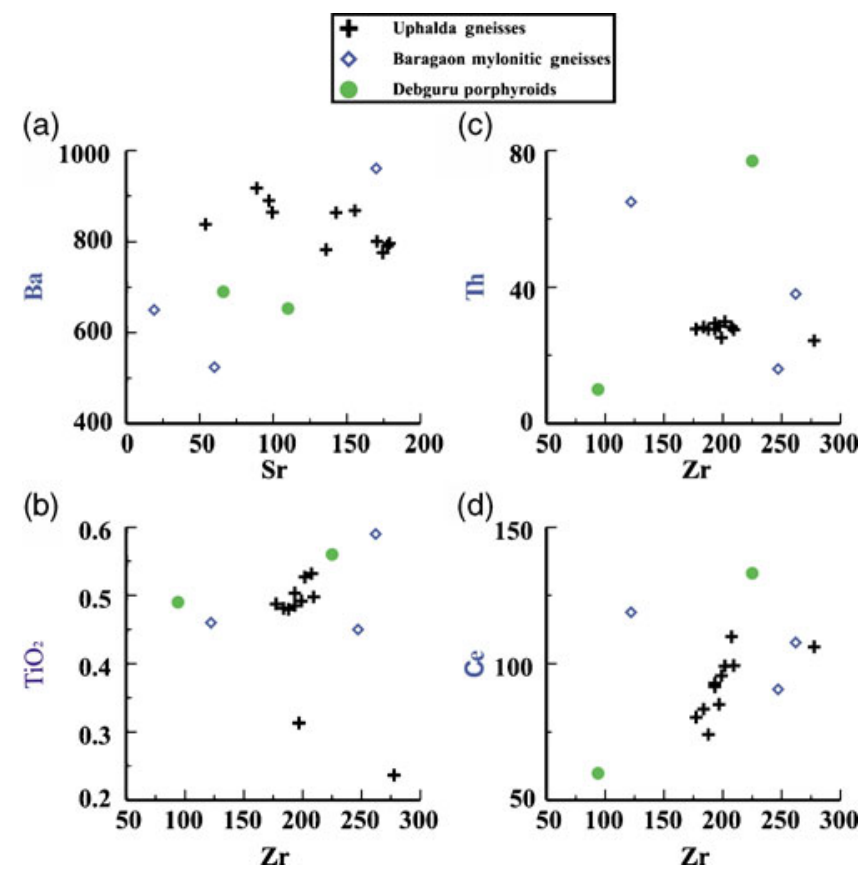

Figure 7. Variation diagrams of $\mathrm{Sr}$ vs. Ba. (a), $\mathrm{Zr}$ vs. $\mathrm{TiO}_{2}$ (b), Zr vs. Th (c), and Zr vs. Ce (d) of UG, DP and BMG. Symbols are as in figure 4.

Zr and both Th and Ce suggest that fractionation of zircon and monazite may have been involved (figure 7c, d). As these phases are much denser than the parental magma and can also form inclu-
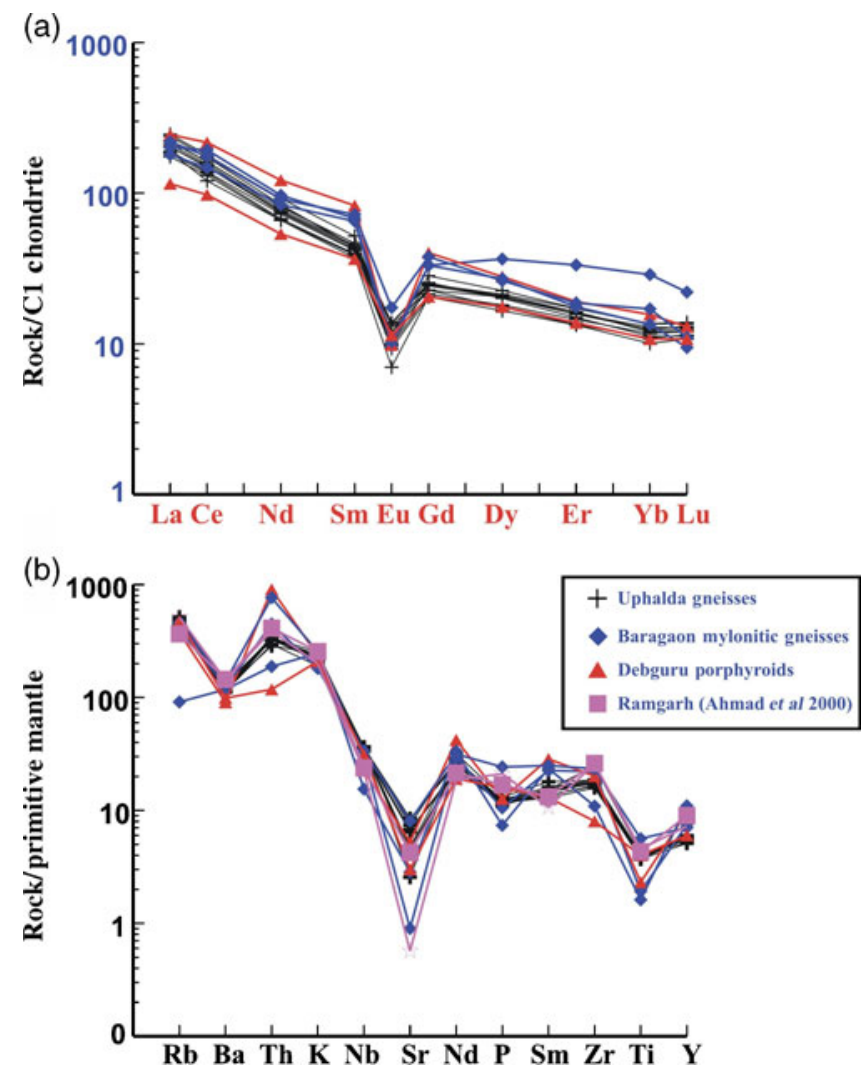

Figure 8. (a) Chondrite normalized REE patterns of UG, DP and BMG. (b) Mantle normalized multi-element spider diagram of UG, DP and BMG. Normalized values (in a, b) are after Sun and McDonough (1989).

sions armoured in major fractionating phases such as biotite. Monazites are rich in LREE and zircons are rich in HREE. Variable fractionation of these phases can play an important role in affecting the REE patterns in the residual melts even if the amount of these minerals is small (Yurimotto et al 1990). Crystallization of these minerals assemblages are favoured in Ca-poor peraluminous granitic rocks such as UG, DP and BMG. Drastic similarities in REE concentration between $\mathrm{UG}, \mathrm{BMG}$ and DP suggest that the source materials are similar in composition before their emplacement.

\section{Discussion}

\subsection{Tectonic implications and regional correlation in the Himalaya}

The preceding description on field geology, petrography and geochemistry of UG, DP and BMG suggests that they are the products of crustal melting of older sedimentary protolith. Petrographic studies of associated Chail metamorphics and the mylonitic augen gneiss show greenschist facies 
condition. The micas, especially biotite, are affected by chloritization in spite of recrystallization. However, albite, microcline and quartz show recrystallization. The crystallized plagioclase is of albitic composition indicating that recrystallization has occurred at lower temperatures. Also the recrystallization of muscovite, epidote, quartz and albite caused by the deformation-induced retrogression of plagioclase reveals that the deformation has taken place in greenschist facies condition. The deformation was initiated at higher temperature (above $350^{\circ} \mathrm{C}$ ) and continued till lowering of temperature. A similar situation observed in UG suggests that before their emplacement as a klippe, these rocks were subjected to deformation that led to the mylonitization of these gneisses.

Geochemically, these granitic gneisses exhibit high molecular A/CNK value, presence of normative corundum and absence of normative diopside, enhanced $\mathrm{Rb} / \mathrm{Sr}, \mathrm{Rb} / \mathrm{Zr}$ ratios, enrichment of Th and contain round zircons; which supports their crustally-derived S-type granitic nature and matches well with S-type granites of White and Chappell (1988). Sedimentary parentage also evident from similarities in REE patterns of granites to those of Post-Archaean Average Australian Shale and North American Shale Composite. The linear plot in major oxide binary plots is interpreted in terms of fractional crystallization processes. Their compositions are controlled by source material, however significant amount of crystal fractionation also played a role in the evolution of these granitoids.

To compare their geochemical similarities, we have used mantle normalized multi-element spider diagram for UG, DP, Ramgarh group of rocks (Ahmad et al 2000) and BMG; and observed drastic similarities in terms of REE and spider diagram such as depletion of $\mathrm{Ba}, \mathrm{Nb}, \mathrm{Sr}, \mathrm{P}$ and $\mathrm{Ti}$ and enrichment of Th (figure $8 \mathrm{~b}$ ).

Mylonitic gneiss is a distinct rock of Lesser Himalaya which occurs as an isolated tectonic sheet within the metasedimentary package such as Chail metamorphites in Himachal Himalaya. The mylonitic gneisses are dated in various sectors of the Himalaya starting from the western sector in the Himachal Himalaya (BMG) to the eastern sector of the Himalaya, Nepal (Ulleri gneisses) and it has yielded $\mathrm{Rb}-\mathrm{Sr}$ whole rock ages between 1800 and $1000 \mathrm{Ma}$ (Bhanot et al 1976, 1978, 1982; Frank et al 1977; Paul et al 1982; Sinha-Roy and Sengupta 1986; Miller et al 2000).

In the western sector of the Himalaya, at the base of the Chail formation, highly deformed gneisses are exposed and are termed as mylonitic augen gneiss. These rocks belong to green schist to lower amphibolite facies metamorphic grades. Further, the protolith of this mylonitic augen gneiss did not intrude into the Haimanta group (Miller et al 2000). Interestingly, Haimantas are considered equivalent to Chails (Islam et al 1999). The mylonitic augen gneisses represent the basement of these Proterozoic metasediments (Trivedi et al 1984; Srivastava and Mitra 1994; Grasemann et al 1999). The whole rock Rb-Sr isochron ages of ca. 1800 Ma for gneisses of Ramgarh thrust hanging wall by Trivedi et al (1984) led Valdiya (1995) to argue that schistose gneisses represent the basement sequence of the Lesser Himalaya. The characteristic association of mylonitic augen gneisses with carbonaceous-graphitic schist and phyllite has been assigned different names in different sections (e.g., Bajjura nappe: Frank et al 1973; Outer granite band: Bhatia and Kanwar 1973; Baragaon gneiss: Bhanot et al 1978; Sewa paragneiss: Sharma et al 1973; Gahr-Manjrot formation: Bassi 1989 and the Ulleri Augen gneiss in the Annapurna region in Nepal: Le-Fort 1975a, 1975b; Pecher and Le-Fort 1977).
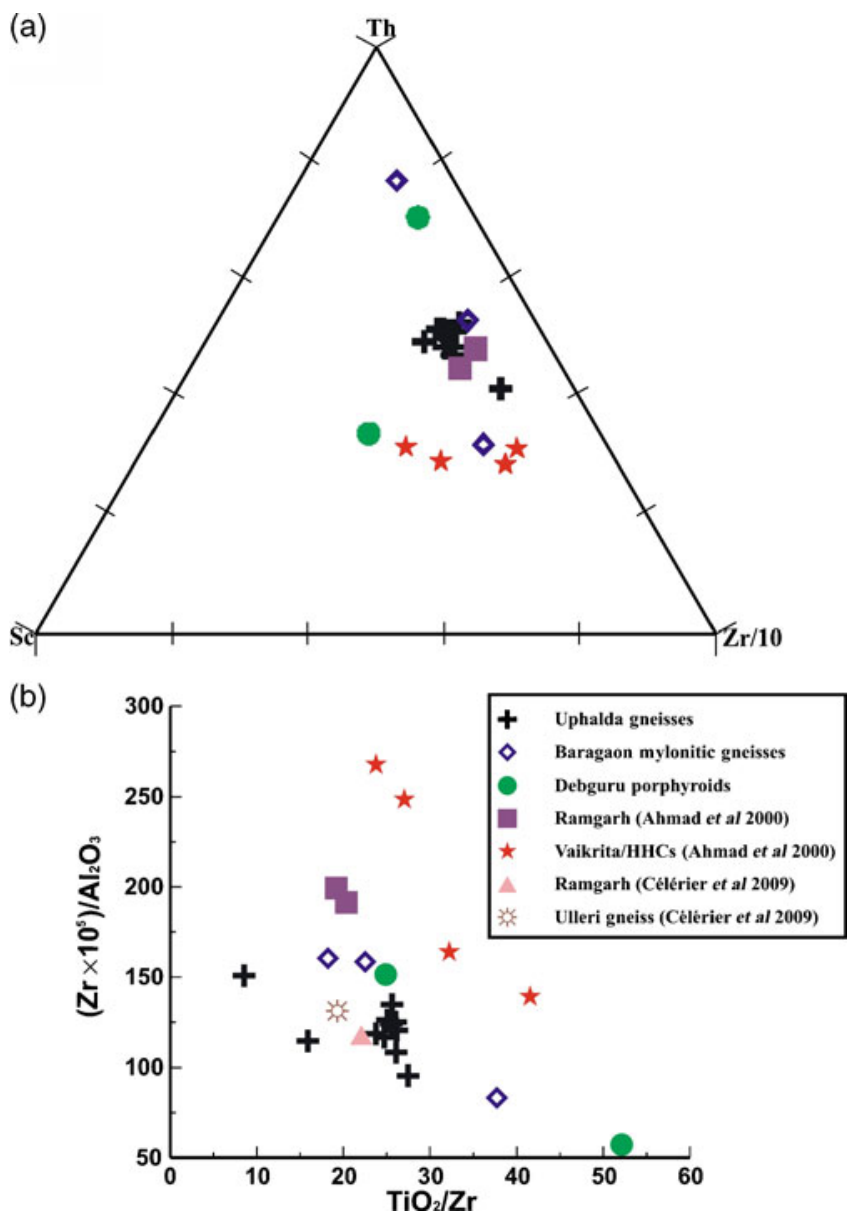

Figure 9. (a) Th-Sc-Zr ternary plot for UG, DP, BMG, Ramgarh and Vaikrita gneisses/HHCs (Ahmad et al 2000) (after Bhatia and Crook 1986). (b) $\left(\mathrm{Zr} \times 10^{5}\right) / \mathrm{Al}_{2} \mathrm{O}_{3}$ vs. $\mathrm{TiO}_{2} / \mathrm{Zr}$ ratio plot of same dataset as in (a) and Ulleri gneisses and Ramgarh (schistose gneiss) data of Célérier et al 2009 (after Fralick and Kronberg 1997). 
To demonstrate that the UG have distinct lithology and can be distinguished from the Higher Himalayan crystallines (HHC), we attempted a ternary plot of immobile elements such as Th, Sc, and $\mathrm{Zr}$ (figure 9a) for the UG, DP and BMG and compared it with data on HHCs ( Vaikrita group) and Ramgarh group by Ahmad et al (2000). The ternary plot indicates that the HHCs rocks are distinct from the UG, DP and BMG. Further, the data on Ramgarh group by Ahmad et al (2000) are compatible with our data. In addition, the ratio of immobile elements can distinguish the source region and such plots remain robust even during high-grade metamorphism (Fralick and Kronberg 1997; Ahmad et al 2000). $\mathrm{Zr} \times 10^{5} / \mathrm{Al}_{2} \mathrm{O}_{3}$ vs. $\mathrm{TiO}_{2} / \mathrm{Zr}$ plots (figure 9b) of UG, DP, BMG and the data on Ramgarh group by Ahmad et al (2000), Célérier et al (2009) (sample no. 0602006 of Mandakini valley and Ulleri gneisses of Nepal) plotted along with HHCs display a distinct identity and can be distinguished from the Lesser Himalayan rocks. The elemental ratio plots are also in conformity with $\mathrm{Nd}-\mathrm{Sr}$ isotopic studies (Ahmad et al 2000; Martin et al 2005) and suggest that UG are comparable with DP, BMG and Ramgarh group of rocks.

Schistose gneisses are widely exposed in the Garhwal-Kumaun region and considered as the basement to the Lesser Himalayan sequence (Valdiya 1995). Crystalline schistose gneiss sample 0602006 of Mandakini valley of Garhwal Himalaya (Célérier et al 2009) was collected from the same locality/ lithology of our DP. These retrogressed schistose gneiss (0602006 of Célérier et al 2009), DP, UG and BMG also suggest an older age for these rock units. Here we suggest UG represent a basement sliver and are emplaced within the cover sequence as wedges in the Lesser Himalaya.

The UG of Srinagar occur as a detached tectonic sheet within the metasedimentary piles of Lesser Himalayan Chandpur phyllites. In the southern parts of UG, the Chandpur formation consists of banded green shale and phyllite; whereas in the northern part, these rocks (Pauri phyllite) gradually change to chlorite-sericite phyllite, followed by chlorite biotite schists and show very well-developed foliation and crenulation cleavages (figure 3e). Resemblance in mineralogy and grade of metamorphism of these rocks is more likely correlatable to the Chail metamorphites of Himachal Himalaya which appears to be reasonable. Similar types of klippen are also observed in Sutlej valley in the Himachal Himalaya. A small gneissic klippe with mylonitic gneissic characters over the Rampur parautochthonous is observed around Shatahal $\left(31^{\circ} 24^{\prime} 41^{\prime \prime}: 77^{\circ} 37^{\prime} 30^{\prime \prime}\right.$; Virdi 1976). The surrounding rocks of Shatahal klippe resemble the Lesser Himalayan rocks of
Srinagar. Therefore, the occurrence of this type of klippe is a regional phenomenon throughout the Lesser Himalayan region.

\section{Conclusions}

Similarities in lithology, petrographic characters and geochemical composition of UG with DP and BMG of Himachal Himalaya suggest that these rocks are not transported from Higher Himalaya as understood earlier (Pilgrim and West 1928; Gansser 1964 and Valdiya 1980). Structural and stratigraphic relations of UG of the Garhwal Himalaya indicate that it represent(s) an older basement sliver which may be tectonically emplaced within the cover sequence as wedges at different structural levels.

\section{Acknowledgements}

We acknowledge the Director, WIHG for providing the necessary facilities to carry out this work. Dr A K Dubey is thanked for discussion in various stages during the preparation of this manuscript. We also thank Drs P P Khanna and N K Saini for chemical analysis. Dr RK Bikramaditya Singh helped us in photomicrographs. The comments of two anonymous reviewers helped us to improve the manuscript.

\section{References}

Ahmad T, Islam R, Khanna P P and Thakur VC 1996 Geochemistry, petrogenesis and tectonic setting of Zildat ophiolite melange of Eastern Ladakh, India; Geodinamica Acta 9(1) 222-233.

Ahmad T, Harris N, Bickle M, Chapman H, Bunbury J and Prince C 2000 Isotopic constraints on the structural relationships between the Lesser Himalayan Series and the High Himalayan Crystalline Series, Garhwal Himalaya; Geol. Soc. Am. Bull. 112 467-477.

Arita K 1983 Origin of the inverted metamorphism of the Lower Himalayas, central Nepal; Tectonophys. 95 43-60.

Auden J B 1934 Geology of the Krol Belt: India; Rec. Geol. Surv. India 67(4) 357-454.

Auden J B 1937 The structure of the Himalayas in Garhwal; Rec. Geol. Surv. India 71 407-433.

Bali R and Bhattacharya A R 1988 Geological and structural studies of the rocks of the Dwarhat-Chaukhutia area, Kumaun Lesser Himalays with special reference to the North Almora Fault; Geosci. J. 9 215-230.

Bassi U K 1989 Delineation of Vaikrita Thrust in Mandi and Kulu districts, Himachal Pradesh; Rec. Geol. Surv. India 122 19-20.

Bhanot V B, Bhandari A K, Singh V P and Goel A K 1976 The petrographic studies and the age determination of Koidal gneiss, Kumaon Himalaya; Curr. Sci. 45(1) 18. 
Bhanot V B, Kwatra A K and Pandey B K 1978 Rb:Sr whole rock age for the Chail Series of Northwestern Himalaya; J. Geol. Soc. India 19 224-225.

Bhanot V P, Bhandari A K, Singh V and Kansal A K 1982 Precambrian (1220 m.y.) Rb-Sr whole rock isochron age for Bandal granite, Kulu, Himalaya, Himachal Pradesh; Geol. Surv. India Misc. Publ. 41 272-277.

Bhatia M R and Crook K A W 1986 Trace element characteristics of graywackes and tectonic setting discrimination of sedimentary basins; Contrib. Mineral. Petrol. 92 181-193.

Bhatia G S and Kanwar R C 1973 Mylonitization in outer Granite Band of Dalhousie, Himachal Pradesh; Himalayan Geol. 3 103-115.

Célérier J, Harrison T M, Yin A and Webb A A G 2009 The Kumaun and Garhwal Lesser Himalaya, India. Part 1: Structure and stratigraphy; Geol. Soc. Am. Bull. 121(9/10) 1262-1280.

DeCelles P G, Robinson D M, Quade J, Ojha T P, Garzione C N, Copeland P and Upreti B N 2001 Stratigraphy, structure, and tectonic evolution of the Himalayan fold-thrust belt in western Nepal; Tectonics 20 487-509.

Devrani U and Dubey A K 2008 Anisotropy of magnetic susceptibility and petrofabric studies in the Garhwal synform, Outer Lesser Himalaya: Evidence of pop-up klippen; Island Arc 18 428-443.

Doval S C and Saklani P S 1980 A note on the study of minor structures in rocks of Srinagar area, Garhwal Himalaya, UP; Himalayan Geol. 10 178-190.

Dubey A K and Bhat M I 1991 Structural evolution of the Simla area, NW Himalayas: Implications for crustal thickening; J. Southeast Asian Earth Sci. 6 41-53.

Fralick P W and Kronberg B I 1997 Geochemical discrimination of clastic sedimentary rock sources; Sedim. Geol. $113111-124$.

Frank W, Hoinkes G, Miller Ch, Purtscheller F, Richter W and Thoni M 1973 Relations between metamorphism and orogeny in a typical section of the Indian Himalayas; Tschermaks Min. Petr. Mitt. 20 303-332.

Frank W, Thoni M and Purtscheller F 1977 Geology and petrography of Kulu-south Lahul area; In: Himalayas. Science de la Terre, CNRS, Paris 268 147-172.

Gansser A 1964 Geology of the Himalayas, Interscience Publishers, John Wiley \& Sons Ltd., London, 289p.

Grasemann B, Fritz H and Vannay J C 1999 Quantitative kinematic flow analysis from the Main Central Thrust Zone (NW Himalaya India): Implications for a decelerating strain path and the extrusion of orogenic wedges; J. Struct. Geol. $21837-853$.

Gururajan N S 1990 Deformation microstructures and geochemistry of the Mylonitic augen Gneisses in the Chail Thrust zone in Satluj valley of Himachal Pradesh; J. Geol. Soc. India 36 290-306.

Hashimoto S, Ohta Y and Akiba C 1973 Geology of the Nepal Himalayas (Tokyo: Saikon publishing Co) 286p.

Heim A A and Gansser A 1939 Central Himalaya; Geological Observations of the Swiss Expedition 1936 (New Delhi: Hindustan Publishing Corporation) 73245.

Hughes N C, Peng S C, Bhargava O N, Ahluwalia A D, Walia S, Myrow P M and Parcha S K 2005 Cambrian biostratigraphy of the Tal Group, Lesser Himalaya, India, and early Tsanglangpuan (late Early Cambrian) trilobites from the Nigali Dhar syncline; Geol. Mag. 142 57-80.

Islam R, Upadhyay R, Ahmad T, Thakur V C and Sinha A K 1999 Pan-African magmatism and sedimentation in the NW Himalaya; Gondwana Res. 2 263-270.

Jayangondaperumal R and Dubey A K 2001 Superposed folding of a blind thrust and formation of kippen:
Results of anisotropic magnetic susceptibility studies from the Lesser Himalaya; J. Asian Earth Sci. 19 $713-725$.

Kohn M J, Catlos E J, Ryerson F J and Harrison T M 2002 Pressure-temperature-time path discontinuity in the Main Central thrust zone, Central Nepal; Geology 30 480-481.

Kretz R 1983 Symbols of rock forming minerals; Am. Mineral. 68 277-279.

Kumar G and Agarwal N C 1975 Geology of SrinagarNandprayag area (Alaknanda valley), Chamoli, Garhwal and Tehri-Garhwal, Kumaun Himalaya, UP; Himalayan Geol. 5 29-59.

LeFort P 1975a Himalayas, the collided range: Present knowledge of the continental arc; Am. J. Sci. 275-A $1-44$.

LeFort P 1975b Les formations cristallophyliennes de la "Dalle du Tibet" en Marsyandi; In: Recherches geologiques dans l'Himalaya du Nepal region du Nyi-Shang (ed.) Bodet P, Paris Editions du Centre National de la Recherche Scientifique, Paris, 21-47.

Lucas-Tooth H and Pyne C 1964 Advances in X-Ray Analysis (New York: Plenum Press) 7523.

Martin A J, DeCelles P G, Gehrels G E, Patchett P J and Isachsen C 2005 Isotopic and structural constraints on the location of the Main Central thrust in the Annapurna Range, central Nepal Himalaya; Geol. Soc. Am. Bull. 117 926-944.

Medlicott H B 1864 On the geological structure and relations to the southern portion of the Himalayan ranges between River Ganga and Ravee; Geol. Surv. India Memoir 3 $1-86$.

Middlemiss C S 1885 A fossiliferous series in the Lower Himalaya, Garhwal; Rec. Geol. Surv. India 18 73-77.

Middlemiss C S 1887 Physical geology of the West British Garhwal; with notes on a route traverse through Jaunsar Bawar and Tehri-Garhwal; Rec. Geol. Surv. India 20 26-40.

Middlemiss C S 1890 Physical geology of the Sub-Himalaya of Garhwal and Kumaun; Rec. Geol. Soc. India 24(2) 59-200.

Miller C, Klotzli U, Frank W, Thoni M and Grasemann B 2000 Proterozoic crustal evolution in the NW Himalaya (India) as recorded by circa $1.80 \mathrm{Ga}$ mafic and $1.84 \mathrm{Ga}$ granitic magmatism; Precamb. Res. 103 $191-206$.

Oldham R D 1883 The geology of Jaunsar and the Lower Himalayas; Rec. Geol. Surv. India 16 193-198.

Oldham R D 1885 Note on the probable age of the Mandhali seies in the Lower Himalaya; Rec. Geol. Surv. India 18 77-78.

Paul D K, Chandy K C, Bhalla J N and Sengupta N R 1982 Geochronology and geochemistry of Lingtse Gneiss, Darjeeling-Sikkim Himalayas; Indian J. Earth Sci. 9 11-17.

Pecher A and Le-Fort P 1977 Origin and significance of the Lesser Himalayan augen gneiss; In: Himalaya Sciences de la Terra. Coll. Internat. Du Centre National de in Recherches Sciences 268 295-329.

Pilgrim G E and West 1928 The structure and correlation of the Simla rocks; Geol. Surv. India Memoir $\mathbf{5 3}$ 1-140.

Richards A, Argles T, Harris N, Parrish R, Ahmad T, Darbyshire F and Draganits E 2005 Himalayan architecture constrained by isotopic tracers from clastic sediments; Earth Planet. Sci. Lett. 236 773-796.

Saklani P S 1972 Lithostratigraphy and structure of the area between Bhagirathi and Bhilangana rivers, Garhwal Himalaya; Himalayan Geol. 2 342-355. 
Searle M P, Waters D J and Stephenson B J 2002 Pressuretemperature path discontinuity in the Main Central thrust zone, Central Nepal; Geology 30 479-480.

Sharma V P, Chaturvedi R K and Sundaram R 1973 An account of the stratigraphy and structure of DodaBhadarwah-Basanthgarh region; Seminar on Geodynamics of the Himalayan Region, NGRI Hyderabad, $110-121$.

Sinha-Roy S and Sengupta S 1986 Precambrian deformed granites of possible basement in the Himalaya; Precamb. Res. 31 209-235.

Srivastava H B and Gairola V K 1990 Structure and deformation history of Dudatoli Crystallines in the Inner Lesser Himalaya, around Srinagar, District Pauri Garhwal, U.P.; J. Himalayan Geol. 1(2) 175-187.

Srivastava P and Mitra G 1994 Thrust geometries and deep structure of the outer and lesser Himalaya, Kumaun and Garhwal (India): Implications for evolution of the Himalayan fold-and-thrust belt; Tectonics 13 89-109.

Sun S S and Mc Donough W F 1989 Chemical and isotopic systematics of oceanic basalts: Implications for mantle composition and processes. In: Magmatism in ocean basins (eds) Sunders A D and Norry M J, Geol. Soc. Spec. Publ. 42 313-345.

Trivedi J R, Gopalan K and Valdiya K S 1984 Rb-Sr ages of the granitic rocks within the Lesser Himalayan nappes, Kumaun, India; J. Geol. Soc. India 25 641-654.

Valdiya K S 1980 Geology of Kumaun Lesser Himalaya, Interim Record: Dehradun, Wadia Institute of Himalayan Geology, 289p.

Valdiya K S 1995 Proterozoic sedimentation and PanAfrican geodynamic development in the Himalaya; Precamb. Res. 74 35-55.

Virdi N S 1976 Stratigraphy and structure of the area around Nirath, district Simla, Himachal Pradesh; Himalayan Geol. 6 163-175.

White A J R and Chappell B W 1988 Some supracrustal (S-type) granites of Lachalan Fold Belt; Trans. R. Soc. Edinburgh, Earth Sci. 79 169-181.

Yurimotto H, Duke E F, Papike J J and Shearer C K 1990 Are discontinuous chondrite normalized REE patterns in pegmatitic granite systems the results of monazite fractionation; Geochim. Cosmochim. Acta 54 2141-2145. 